\title{
Study of a pilot photovoltaic-electrolyser-fuel cell power system for a geothermal heat pump heated greenhouse and evaluation of the electrolyser efficiency and operational mode
}

\author{
lleana Blanco, Simone Pascuzzi, Alexandros Sotirios Anifantis, Giacomo Scarascia-Mugnozza \\ Department of Agricultural and Environmental Science, University of Bari Aldo Moro, Bari, Italy
}

\begin{abstract}
The intrinsic factor of variability of renewable energy sources often limits their broader use. The photovoltaic solar systems can be provided with a power back up based on a combination of an electrolyser and a fuel cell stack. The integration of solar hydrogen power systems with greenhouse heating equipment can provide a possible option for powering stand-alone greenhouses. The aim of the research under development at the experimental farm of Department of AgroEnvironmental Sciences of the University of Bari Aldo Moro is to investigate on the suitable solutions of a power system based on photovoltaic energy and on the use of hydrogen as energy vector, integrated with a ground source heat pump for greenhouse heating in a self sustained way. The excess energy produced by a purpose-built array of solar photovoltaic modules supplies an alkaline electrolyser; the produced hydrogen gas is stored in pressured storage tank. When the solar radiation level is insufficient to meet the heat pump power
\end{abstract}

Correspondence: Ileana Blanco, Department of Agricultural and Environmental Science, University of Bari Aldo Moro, via Amendola 165/A, 70126, Bari, Italy.

Tel/Fax: +39.080.544.29.77.

E-mail: ileana.blanco@uniba.it

Key words: alkaline electrolyser, energy savings, greenhouses, hydrogen.

Acknowledgements: the present work has been carried out under the project Produzione integrata di energia da fonti rinnovabili nel sistema agroindustriale regionale - Reti dei laboratori pubblici di ricerca (project cod. RTL 01) cofunded by the Regione Puglia under the Accordo di Programma Quadro in materia di Ricerca Scientifica - II Atto Integrativo - PO Puglia FESR 20072013, Asse I, Linea 1.2 - PO Puglia FSE 2007-2013 Asse IV.

Contributions: the experimental tests, the data processing and the editorial work must be shared equivalently among the Authors within the areas of their expertise.

Received for publication: 12 June 2014.

Accepted for publication: 1 September 2014.

(C) Copyright I. Blanco et al., 2014

Licensee PAGEPress, Italy

Journal of Agricultural Engineering 2014; XLV:238

doi:10.4081/jae.2014.238

This article is distributed under the terms of the Creative Commons Attribution Noncommercial License (by-nc 3.0) which permits any noncommercial use, distribution, and reproduction in any medium, provided the original author(s) and source are credited. demand, the fuel cell starts converting the chemical energy stored by the hydrogen fuel into electricity. This paper reports on the description of the realised system. Furthermore the efficiency and the operational mode of the electrolyser were evaluated during a trial period characterised by mutable solar radiant energy. Anyway the electrolyser worked continuously in a transient state producing fluctuations of the hydrogen production and without ever reaching the steady-state conditions. The Faradic efficiency, evaluated by means of an empirical mathematic model, highlights that the suitable working range of the electrolyser was $1.5 \div 2.5 \mathrm{~kW}$ and then for hydrogen production more than $0.21 \mathrm{Nm}^{3} \mathrm{~h}^{-1}$.

\section{Introduction}

Greenhouses are one of the most innovative expressions of modern agriculture, widespread in many nations particularly and it is expected for them to expand more and more in future, especially in the areas with unfavourable climatic conditions (Baldoin et al., 2008; Schettini et al., 2008; Giacomelli et al., 2012; von Zabeltitz, 1999).

Advanced greenhouses mainly need energy for heating systems; in the horticultural and floricultural sector, winter heating for greenhouses can be the $70 \%$ of production costs (Scarascia-Mugnozza and Anifantis, 2009; Vox et al., 2008).

In the Mediterranean area greenhouses need much less energy than in Northern Europe. De Pascale and Maggio (2005) observed that in Southern Italy one hectare of cut roses requires about 5200-6800 GJ/year vs 16,000 GJ/year required in Netherlands for the same production. Nevertheless the great majority of the greenhouses depend on fossil energy sources (Vox et al., 2010). Therefore the use of fossil fuel for greenhouse heating has a major impact on the cost and on the environmental sustainability of vegetable production (ScarasciaMugnozza et al., 2011).

Agricultural buildings, thanks to their low ratio between built area and agricultural land, represent an interesting sector of applicability for geothermal heat pump technologies. A greater size of the ground heat exchangers is requested for systems with superior heat capacity; therefore these technologies are suitable when large agricultural areas are available (Chiabrando and Fabrizio, 2009). The geothermal heating systems are economically advantageous having a low environmental impact on the agricultural sector applications and especially for greenhouse heating demands (Benli, 2013; Chai et al., 2012; Scarascia-Mugnozza et al., 2011; Ozgener, 2010; Kondili and Kaldellis, 2006; Adaro et al., 1999).

The intrinsic variability and unpredictable availability of renewable energy sources often limit their wider use. Therefore renewable energy based systems need a power back up arrangement; the commonly used batteries have limited lifetime and low energy storage capacity. 
The solar systems can be provided with a power back up consisting in a combination of an electrolyser and a fuel cell stack. In this case renewable energy sources are employed to generate high purity hydrogen gas through water electrolysis process. Produced hydrogen behaves as an energy vector which can store the photovoltaic energy exceeding the greenhouse current demand, and it can be used later for power generation by the fuel cell.

Hydrogen can be produced through different processes. At present worldwide hydrogen production is set up on fossil sources using natural gas reforming process or coal gasification (Mueller-Langer et al., 2007). It is worthwhile mentioning the hydrogen production by thermal processing of biomass, as the biomass pyrolysis, and by biological methods that offer the possibility of using sunlight, carbon dioxide $\left(\mathrm{CO}_{2}\right)$ and organic wastes as substrates (Redwood et al., 2009). The biological methods for generating $\mathrm{H}_{2}$ include light-dependent methods, such as direct and indirect biophotolysis and photo-fermentation and not light-dependent methods such as dark fermentation process (Kapdan, 2006; Gómez et al., 2011). The dark fermentative hydrogen production from biomass and wastes refers to the exploitation of microorganisms that are capable of converting organic matter to acids and alcohols with simultaneous liberation of molecular hydrogen (Ntaikou et al., 2010).

Water electrolysis is the only one without carbon dioxide emissions in atmosphere and when associated to electricity produced from renewable sources, it generates zero emissions electricity (Casadei et al., 2005) contributing to reduce fossil sources energy application.

Hydrogen production systems powered by stand-alone photovoltaic generators are characterised by considerable superiority (Valdés et al., 2012): they can be set in areas not yet supplied with electric grid, avoiding expensive investments for a single electric grid implementation; they meet fuel local need in one place eliminating transport costs of hydrogen; they contribute to improve standards of living in rural areas.

They can operate reliably under dynamic solar irradiance and dynamic loads, even though an economic analysis showed that such systems are still far from being cost competitive (Maclay et al., 2011).

A lot of research have been carried out and are still under development on the solar (photovoltaic and wind)-electrolyser-fuel cell hybrid power systems with backup consisting in hydrogen storage systems (Khan and Iqbal, 2005; Jallouli and Krichen, 2012) in support of the feasibility and reliability of solar hydrogen power systems. The conventional storage methods consist in storing hydrogen as a gas in pressurised gas cylinders or as a liquid in cryogenic tanks; in the context of the innovative methods still under research, metal hydrides and complex hydrides permit to store hydrogen safely and efficiently (Züttel, 2003). The storage of the hydrogen in the form of a gas poses several problems still waiting for a solution, because pressured hydrogen gas takes a great deal of volume compared with other fuels like, for example, gasoline that, with equal energy content, needs about 30 times lesser volume at $10 \mathrm{MPa}$ gas pressure (David, 2005). However the low hydrogen energy density by volume is not a great problem for stationary applications.

Few studies have investigated on the integration of solar hydrogen power systems with greenhouses although these systems can provide a possible option for powering stand-alone greenhouses (Ganguly et al., 2010).

The research under development at the Department of Agricultural and Environmental Science of the University of Bari Aldo Moro aims to investigate the suitable solutions of a pilot power system, based on solar energy (photovoltaic) and hydrogen, powering a self sustained greenhouse heated with a geothermal heat pump. The present work is a first contribution to the description of the system and of the expected results. Furthermore the efficiency and the operational mode of the electrolyser, a crucial component of the integrated system, are studied evaluating its performance during a trial period characterised by mutable solar radiant energy in the location where the pilot power system has been realised.

\section{Design and description of the system}

The experimental set-up consists of a solar photovoltaic-hydrogen generating pilot plant which powers a low enthalpy geothermal heat pump used to heat a greenhouse through a hot water floor system. The power system has been designed for supplying the electric loads demanded by the ground source heat pump of the experimental greenhouse.

The study was carried out at the experimental farm of the University of Bari sited in Valenzano (location latitude $41^{\circ}, 1^{\prime}, 12$ ", longitude $16^{\circ}$, 54', 16"), Bari, Southern Italy, where a greenhouse-integrated system composed of photovoltaic panels, an alkaline electrolyser bank, the polymer electrolyte membrane fuel cell stacks, a plastic covered greenhouse and a geothermal heat pump were set up. The electric power generated by the solar photovoltaic source (PV) feeds the electrolyser which, in turn, produces hydrogen gas by water electrolysis. The hydrogen is then stored in a pressure tank and, when photovoltaic is not operative (during night time or overcast sky), it is used by a fuel cell system producing electricity for greenhouse energy demands.

\section{The experimental greenhouse}

The passive load is the heating system which has to cover the thermal energy demand of $48 \mathrm{~m}^{2}$ double plastic skin greenhouse.

The main structure of the greenhouse, with arched shape roof, is made of tubular galvanised steel. The base and the gable walls (east and west-facing greenhouse surface) are made of glass-reinforced plastic corrugated sheets. The covering is made of a double sheet of ethylene vinyl acetate film (multi EVA 33 AD AF), each one having a thickness of $200 \mu \mathrm{m}$, with a $4 \mathrm{~cm}$ air gap kept under constant pressure by an air fan. The greenhouse is provided with a vertical fan, an air inlet louver and a door, placed on a single gable wall.

An unheated greenhouse, with the same geometric and constructive characteristics and orientation (east-west direction) than the heated one, has been realised for control (Figure 1).

The two greenhouses are $8.0 \mathrm{~m}$ in length and $6.0 \mathrm{~m}$ in width, $3.5 \mathrm{~m}$ height at the ridge; the cladding surface is $120 \mathrm{~m}^{2}$ and the volume is $150 \mathrm{~m}^{3}$.

The distance between the two greenhouses is $12.0 \mathrm{~m}$ to avoid mutual shading.

The necessary heating power $Q_{H}(\mathrm{~W})$ during the night time was eval-

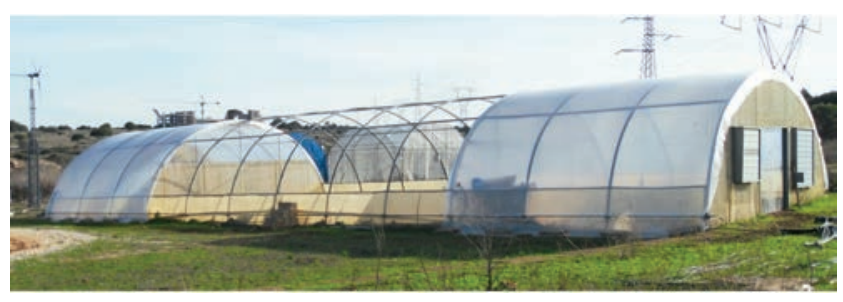

Figure 1. Experimental greenhouses. 
uated using the heat balance (De Luca et al., 1996; Walker and Short, 1983) taking into consideration the main power losses:

$$
Q_{H}=Q_{c}+Q_{v}+Q_{i}
$$

where:

$Q_{c}$ is the conduction and convection power loss through the greenhouse covering system $(\mathrm{W})$;

$Q_{v}$ is the air leakage power loss from indoor to outdoor environment (W);

$Q_{i}$ is the power loss by radiation from the covering (W).

The greenhouse heating system was made of black plastic hose; the heat pump is a $7.2 \mathrm{~kW}$ low-enthalpy geothermal system with a heating capacity of $7.2 \mathrm{~kW}$ and an electric power consumption of $1.5 \mathrm{~kW}$, equipped with $120 \mathrm{~m}$ vertical double U-bend ground heat exchangers.

\section{The hybrid system}

The pilot power plant allows using the photovoltaic production both directly to supply the greenhouse energy demand or to produce hydrogen (Figure 2). The array of photovoltaic panels consists of 24 modules of $240 \mathrm{~W}$ peak power, maximum operating voltage $29.64 \mathrm{~V}$. The PV modules have a total area around $39 \mathrm{~m}^{2}$, south-oriented with an elevation angle of $30^{\circ}$ in order to maximise annual energy production. The PV modules have been set up on a tubular galvanised steel structure. PV modules are connected in parallel, resulting in an array supplying a nominal voltage output of $360 \mathrm{~V}$. The direct current (DC) generated by the PV array is converted to alternating current (AC) by an inverter in order to power the water electrolyser. The AC power could also feed the grid. The inverter has an input voltage of 300-600 VDC and an output AC voltage of $230 \mathrm{VAC}$.

The alkaline barometric electrolyser used in this study, placed in the process unit, is of patented design VOLTIANA ${ }^{\circledR}$, a Casale Chemicals SA (Lugano, Switzerland) trademark (Sioli, 2014). It has an input voltage of $230 \mathrm{VAC}$ and is able to operate from $20 \%$ to $100 \%$ of its power rating, which is $2.5 \mathrm{~kW}$ (Figure 3 ). The hydrogen production rate is proportional to the AC intensity applied to cell stack and the hydrogen nominal production rate is $0.4 \mathrm{Nm}^{3} \mathrm{~h}^{-1}$ with output pressure of $3 \mathrm{MPa}$ at $100 \%$ rated power. Potassium hydroxide (KOH 28\%) is added to the contained water in order to make the electrolyte highly conductive. The electrolyser requires demineralised water at atmospheric pressure and its consumption at full load is $45 \times 10^{-5} \mathrm{~m}^{3} \mathrm{~h}^{-1}$.

The produced hydrogen, pressurised at $3 \mathrm{MPa}$, is stored in two steel tanks of $0.6 \mathrm{~m}^{3}$ placed nearby the shelter (Figure 4 ). The system for the hydrogen production is formed also by other auxiliary parts (pumps, and so on) which globally require a constant electric power $P_{a u x}=0.6 \mathrm{~kW}$ for their working.

The proton exchange membrane fuel cell system is placed in the process unit of the cabinet and is designed with modular cartridge technology, having a peak power of $2 \mathrm{~kW}$.

The fuel cell requires industrial grade hydrogen (99.95\%) and oxygen (from the air) and produces pure water/vapour and heat as byproducts; the output voltage is of $48 \mathrm{VDC}$ and the consumption is of 1.8 $\mathrm{Nm}^{3} \mathrm{~h}^{-1}$ at $2 \mathrm{~kW}$ (the operation environment temperatures range is $2{ }^{\circ} \mathrm{C} \div 46^{\circ} \mathrm{C}$ ).

The energy produced by the fuel cells is used to charge a battery bank consisting of six $12 \mathrm{~V}$ cells connected in series and in parallel providing a nominal energy capacity of $900 \mathrm{Ah}$.

An inverter is connected to the battery terminals in order to be used as a stand-alone AC power supply.

The monitoring and control system, placed in the control unit, is based on a programmable logic controller (PLC) Horner PLC XL6 OCS (Horner APG Corp., Indianapolis, IN, USA) and is integrated with a

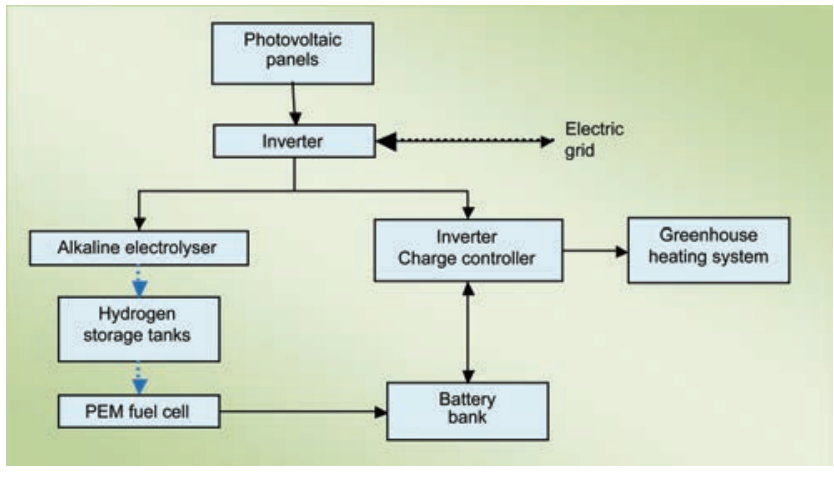

Figure 2. Functional diagram of the pilot plant. PEM, proton exchange membrane.

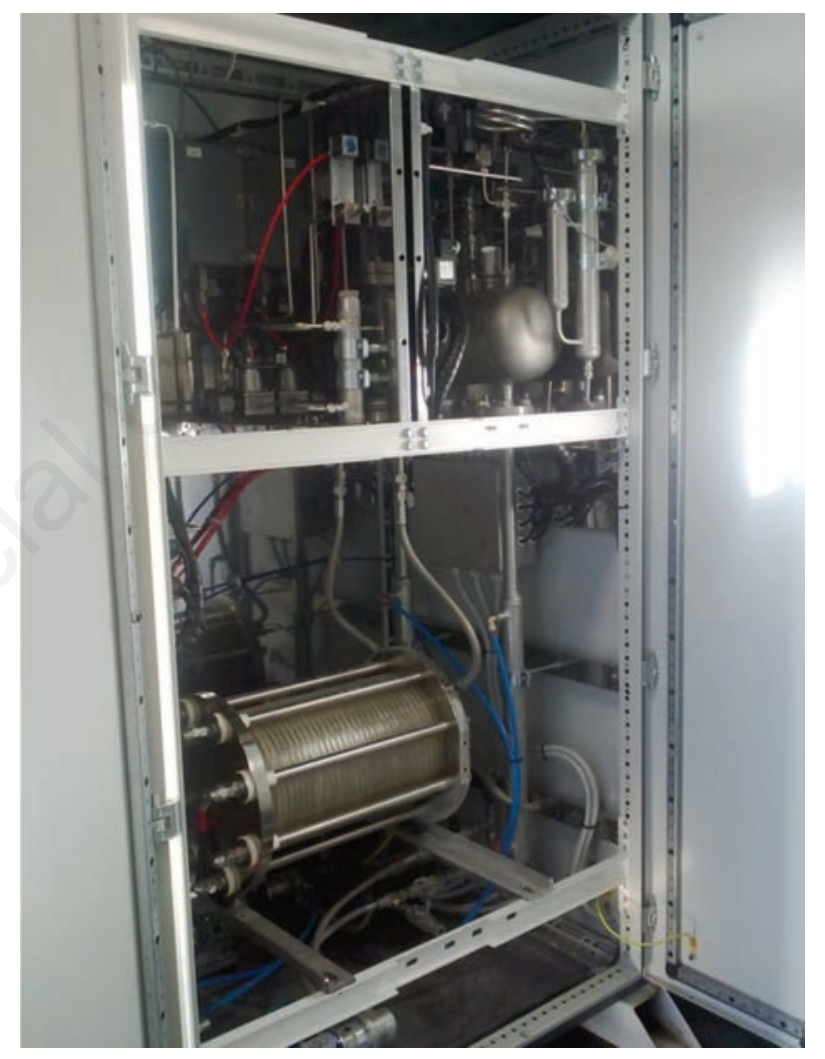

Figure 3. The electrolyser bank.

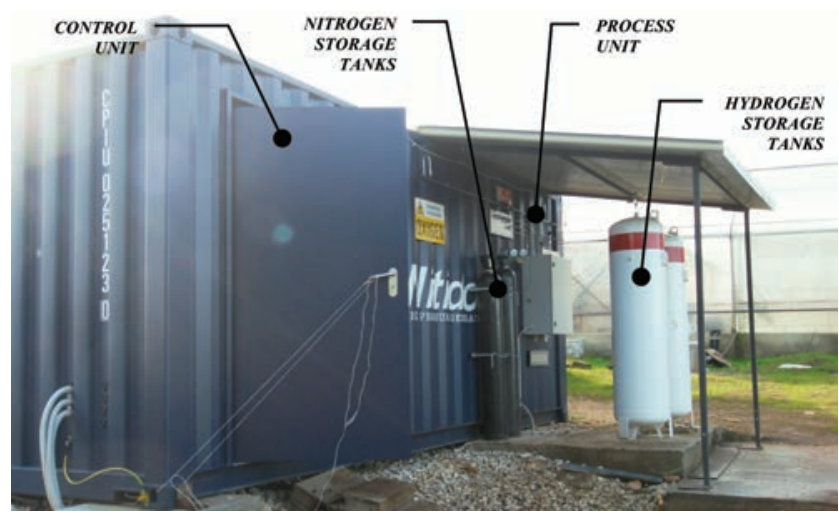

Figure 4. Pilot plant external layout. 
power supply unit. The PLC manages all the safety procedures.

The energy system, except for PV arrays or hydrogen and nitrogen storage tanks, is enclosed in a steel shelter (Figure 4) made up of two separate chambers enclosing the process unit and the power supply unit, respectively. The process unit contains the fuel cells and all the equipment, piping and field instruments necessary for the water electrolysis process.

This system has been set up and it has been finished in April 2013. Starting from the month of May 2013 some operation tests have been carried out paying attention on the electrolyser functionality.

\section{Materials and methods}

\section{Theoretical considerations concerning the electrolyser}

The cell stack, the core of a water electrolyser unit, is made of a certain number of bipolar electrolytic cells. Hydrogen and oxygen are generated inside the cells following the chemical equations:

cathode: $2 \mathrm{H}_{2} \mathrm{O}+2 \mathrm{e}^{-}=>2 \mathrm{OH}^{-}+\mathrm{H}_{2}$

anode: $2 \mathrm{OH}^{-}=>\mathrm{H}_{2} \mathrm{O}+1 / 2 \mathrm{O}_{2}+2 \mathrm{e}^{-}$

global: $\mathrm{H}_{2} \mathrm{O}+$ electrical energy $=>\mathrm{H}_{2}+1 / 2 \mathrm{O}_{2}$

According to Faraday's law, the production rate of hydrogen in an electrolyser is directly proportional to the transfer rate of electrons at the electrodes, which in turn is equivalent to the electrical current in the external circuit. The overall hydrogen production rate $q_{H 2}\left(\mathrm{~mol} \mathrm{~s}^{-1}\right)$ in the electrolyser formed with $n_{c}$ cells connected in series can be computed by (Li et al., 2009):

$$
q_{H_{2}}=\eta_{F} \cdot \frac{n_{c} \cdot I}{z \cdot F}
$$

where:

$z$ is the number of charges transferred per hydrogen molecule $(z=2)$; and

$F$ the Faraday's constant $\left(96,485 \mathrm{C} \mathrm{mol}^{-1}\right)$;

$\eta_{F}$ is the Faradic efficiency of the electrolyser.

On the other hand the power $P_{r}(\mathrm{~W})$ required by the electrolyser for its operation is (Li et al., 2009):

$$
P_{r}=U_{c} \cdot n_{c} \cdot I=U \cdot I
$$

where:

$U_{c}$ is the difference of potential between anode and cathode of each electrolysis cell operating with an electric current $I(\mathrm{~A})$; and $U$ is the voltage supplied to the electrolyser.

Therefore taking into account equation (3) and considering hydrogen an ideal gas with molar volume of $22,414 \cdot 10^{-3} \mathrm{~m}^{3} \mathrm{~mol}^{-1}$ at $0^{\circ} \mathrm{C}$ and $101,325 \mathrm{kPa}$ (standard condition), equation (2) can be rearranged to calculate the hydrogen gas flow rate $\left(\mathrm{Nm}^{3} \mathrm{~h}^{-1}\right)$ :

$$
Q_{H_{2}}=80.69 \cdot \eta_{F} \cdot \frac{n_{c} \cdot I}{z \cdot F}=80.69 \cdot \eta_{F} \cdot \frac{n_{c} \cdot P_{r}}{U \cdot z \cdot F}
$$

The Faradic efficiency is a way to assess the electrolysis system and it is calculated by the ratio between the effective and theoretical maximum amount of hydrogen produced in the electrolyser.

The Faradic efficiency can be computed from equation (4):

$$
\eta_{F}=\frac{U \cdot z \cdot F \cdot Q_{H_{2}}}{80.69 \cdot n_{c} \cdot P_{r}}
$$

It is often called current efficiency because it is linked to parasitic current losses along the gas ducts. Lower Faradic efficiencies are caused by temperature raising that produces less resistance and more parasitic current losses.

A simplified Faradic efficiency empirical expression that precisely portrays these phenomena for a given temperature is (Ulleberg, 2003):

$$
\eta_{F}=k_{1} \cdot \frac{\left(\frac{I}{A}\right)^{2}}{k_{2}+\left(\frac{I}{A}\right)^{2}}=k_{1} \cdot \frac{\left(\frac{P_{r}}{U \cdot A}\right)^{2}}{k_{2}+\left(\frac{P_{r}}{U \cdot A}\right)^{2}}
$$

where $A$ is the area of the electrode, which for the electrolyser under test is $100 \mathrm{~cm}^{2}$.

The parameters $\mathrm{k}_{1}$ and $\mathrm{k}_{2}\left[\mathrm{~mA}^{2} \mathrm{~cm}^{-4}\right]$ are related to the characteristic of the electrolyser and usually are linearly affected by the temperature (Ulleberg, 2003). They have been evaluated according to the technical characteristics of the electrolyser reported by the manufacturer and on the strength of data in literature (Hug et al., 1992; Ulleberg, 2003): $k_{l}=0.934 ; k_{2}=1500\left[\mathrm{~mA}^{2} \mathrm{~cm}^{-4}\right]$.

The electrolyser, formed by $n_{c}=33$ cells, is supplied by means of an electric power supply (3.5 kW-230 VAC), basically consisting of an aircooled transformer-rectifier group, which converts the $\mathrm{AC}$ current into DC current. A control system assures that the terminal voltage $U$ at the electrolyser works in the range $64-70 \mathrm{~V}$.

\section{Experimental data}

The performance of the electrolyser was evaluated employing only the electrical power supplied by the PV modules during the period 1 to 31 March 2014, during which the solar radiation has been very unstable, then affecting the available electrical power produced by the PV. Obviously the electrolyser worked only during the daytime but the actual working time of hydrogen production was less than the daytime because some restraints influenced its effectiveness. Indeed the hydrogen production cycle inside the electrolyser occurred only when the available electric power $P_{d}$ coming from the PV modules was higher than the $20 \%$ of its power rating. The available electric power $P_{d}(\mathrm{~W})$ was evaluated by a control system provided by means of the following equation:

$$
P_{d}=P_{s}-P_{g p}-P_{a u x}
$$

where:

$P_{s}$ was the power produced by $\mathrm{PV}$ modules $(\mathrm{W})$;

$P_{g p}$ is the required power for the working of the geothermal heat pump used for heating a greenhouse (W); and

$P_{a u x}$ the required power for the other auxiliary parts of the plant (W).

Furthermore the hydrogen production occurred properly only when the pressure inside the electrolyser was higher than 2.8 $\mathrm{MPa}$ and a safety system cut off the electrolysis process if the pressure turned higher than $3 \mathrm{MPa}$. Finally, in order to eliminate the air a purging operation of the electrolyser was carried out by means of nitrogen before each start and shut down of the electrolyser.

Experimental measurements of hydrogen production rate and the corresponding required electric power were recorded respectively by means of an inline mass flow meter installed on the output pipeline of the hydrogen purification unit, and a voltmeter - ammeter assembled on the electric feeder of the electrolyser. The controller Horner PLC XL6 OCS (Horner APG Corp.) processed the electrical signals coming from these devices with sampling frequency of $1 \mathrm{~min}$. Other process conditions of hydrogen temperature and pressure, liquid levels, as well as the working conditions of the PV panels were also input to the con- 
troller, which gave rise to output signals to automatically manage the hybrid system. Within the aim of this paper, the main component of the measure chain is the thermal mass flow meter Bronkhorst model Select MFM F-111BI (Bronkhorst High-Tech B.V., Ruurlo, Netherlands), which allowed measuring the mass flow or the standard volumetric flow irrespective of pressure and temperature. According to the manufacturer, on the average the measured values by this device are different from the actual ones of $\pm 0.5 \%$ (accuracy) and are less than $0.2 \%$ close to each other (precision) (ISO 5725-1:1994; ISO, 1994). The range of flow that this thermal mass flow meter is able to measure with acceptable accuracy is 1:50 (turndown) that is from 0.01 to $0.5 \mathrm{Nm}^{3} \mathrm{~h}^{-1}$.

\section{Results and discussion}

The pilot power plant, composed mainly of photovoltaic panels, alkaline barometric water electrolyser and fuel cell stacks, has been designed for supplying the electric loads demanded by the ground source heat pump of the experimental greenhouse. The design has taken into account the average climatic data measured at the experimental farm of the University of Bari during the winter season of the last five years. The study expects to establish a pilot plant suitable for supplying the geothermal heat pump in a self-sustained way during the cold periods, that is to find that there is a positive gap between the hydrogen generation (in electrolyser) and its consumption in fuel cell stack for representative periods of the cold months of the year.

The climate conditions of March 2014 in Valenzano were mainly characterised by clear sky or partially cloudy sky and, for example, Figure 5 shows the photovoltaic electrical production $(\mathrm{kW})$ throughout the daytime 25-31/03/2014. The electrolyser started to produce hydrogen when the photovoltaic production was greater than $1.1 \mathrm{~kW}$. Actually, analysing equation (7), during these days the geothermal heat pump did not work $\left(P_{g p}=0\right)$, the constant required power for the other auxiliary parts of the plant was $P_{a u x}=0.6 \mathrm{~kW}$ and the $20 \%$ of the electrolyser power rating ( 2.5 $\mathrm{kW}$ ) was $0.5 \mathrm{~kW}$. During the days characterised by partially cloudy sky, as for instance from March 25 to 28 (Figure 6), the operation of the electrolyser was very unstable and various breakdowns of hydrogen production occurred. These discontinuous conditions took place also repeatedly during the daytime and caused low actual working times of the electrolyser, taking into account that before each restarting it needed to execute the washing of the plant with nitrogen and then to wait that the pressure inside the electrolyser reached the threshold value of $2.8 \mathrm{MPa}$. On the contrary, during the days characterised by clear sky, the electrolyser worked continuously even if the $\mathrm{H}_{2}$ production was affected by the PV current intensity that changed with the solar elevation during the daytime (Figure 5). Taking into account everything mentioned above the electrolyser operated under unstable conditions and always worked in a transient state with endless fluctuations of the $\mathrm{H}_{2}$ production (Figure 6). Probably this operating manner of the electrolyser explains the graph concerning the measured amount of produced hydrogen as a function of the stack required power reported through a continuous line in Figure 7. The $\mathrm{H}_{2}$ rate flow increases with the increasing of the stack required power, even if the trend of the graph highlights a not directly proportionality between these two quantities. Therefore this result may be correlated to the working manner of the electrolyser, which continuously has to adjust itself to changeable operative conditions without ever reaching steady-state requirements. The experimental data are compared, in Figure 7, with data calculated by means of equations (4) and (6). The two graphs are significantly different but it needs to highlight that equation (4) is a linear function and is generally used to describe the steady state or stationary behaviour of the electrolyser. This mathematical model allows only a simplified approach that does not consider the physical state of the electrolyser (pressure, temperature, bubbling, electrolyte concentration, etc.) and therefore cannot evaluate appropriately the correlation between $\mathrm{H}_{2}$ rate flow and stack required power in transient regimens. Nevertheless the graph regarding the Faradic efficiency as a function of the required stack power, reported through a continuous line in Figure 8 has been built through equation (5), using the experimental data concerning the amount of produced hydrogen and the corresponding required stack power. Once again this graph highlights the considerable unstableness of the working conditions of the electrolyser. The graph concerning $\eta_{F}$ as a function of the required power, built by means of equation (6), is also reported with a dotted line in Figure 8. It is significant that the trend of the graph of experimental Faradic efficiency of Figure 8 is consistent with the one concerning the measured amount of

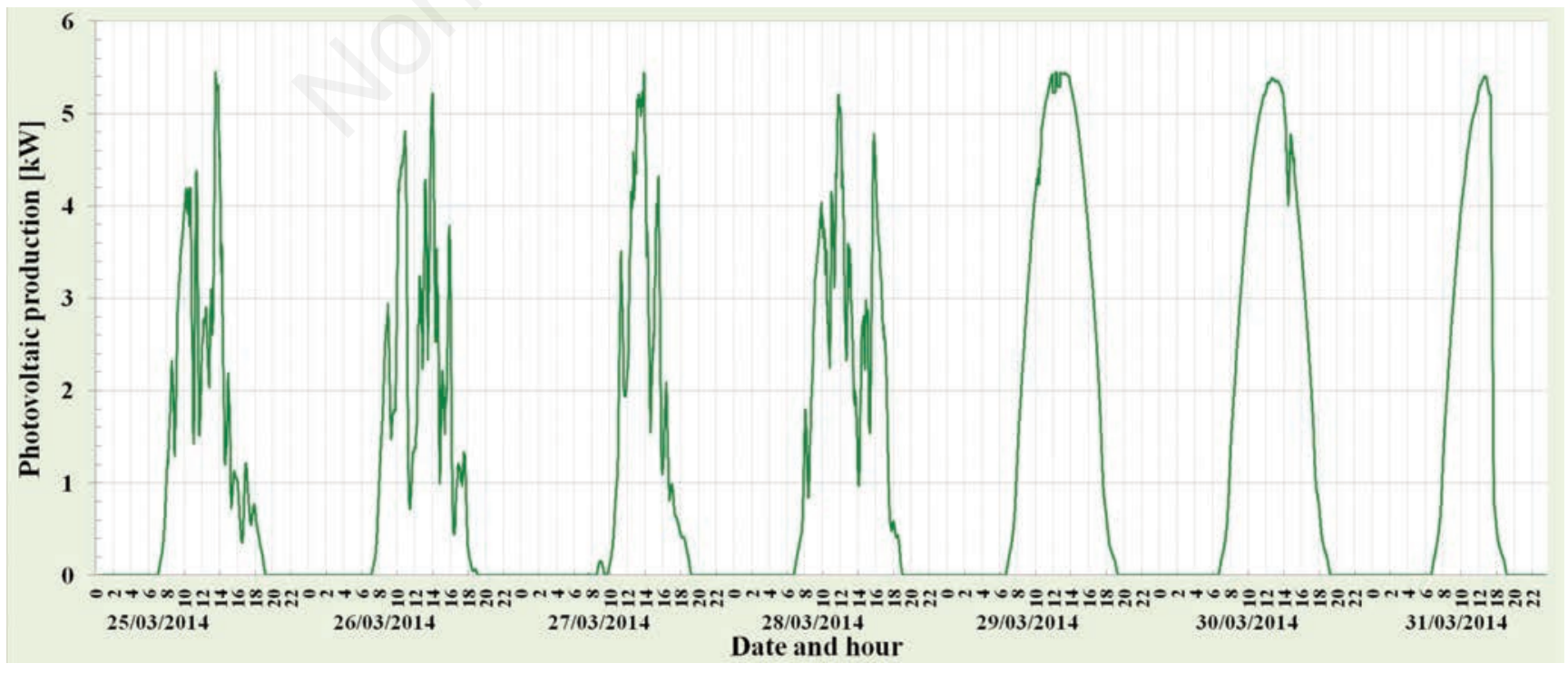

Figure 5. The photovoltaic production (2014 March, 25-31). 
produced hydrogen reported in Figure 7: both the graphs cross the corresponding calculated graphs at the same values of required power by the electrolyser and the range in which the experimental curves are over or under the corresponding calculated curves are just the same. The two graphs of the Figure 8 cannot be compared each other because are obtained following two ways absolutely different. The Faradic efficiency valuated through the experimental data cannot be generalisable because it is strongly affected by the instantaneous variability of the operative condition of the electrolyser (PV current, solar radiation, temperature and pressure inside the electrolyser, and so on) and therefore it does not satisfy the condition of reproducibility. Actually different operative conditions of the electrolyser would produce a graph of the Faradic efficiency as a function of the required stack power strongly divergent if compared with the one reported in Figure 8. Finally also equation (6), like the concerning graph of the Figure 8 , is a rough model because its accuracy is affected by the evaluation of the parameters $k_{1}$ and $k_{2}$. Nevertheless this empirical approach allows the following remarks about the electrolyser performance. The Faradic efficiency range increases with the increasing

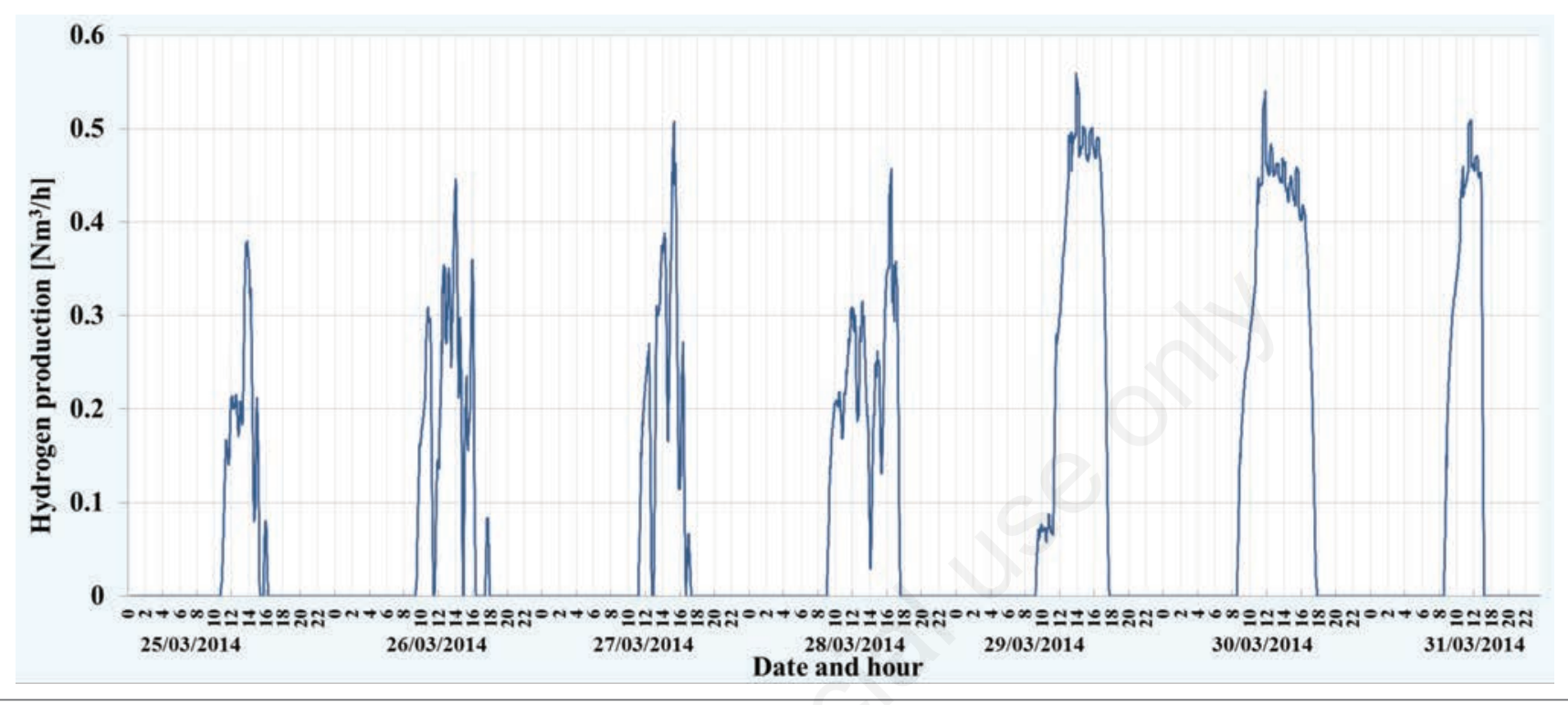

Figure 6. The hydrogen production (2014 March, 25-31).

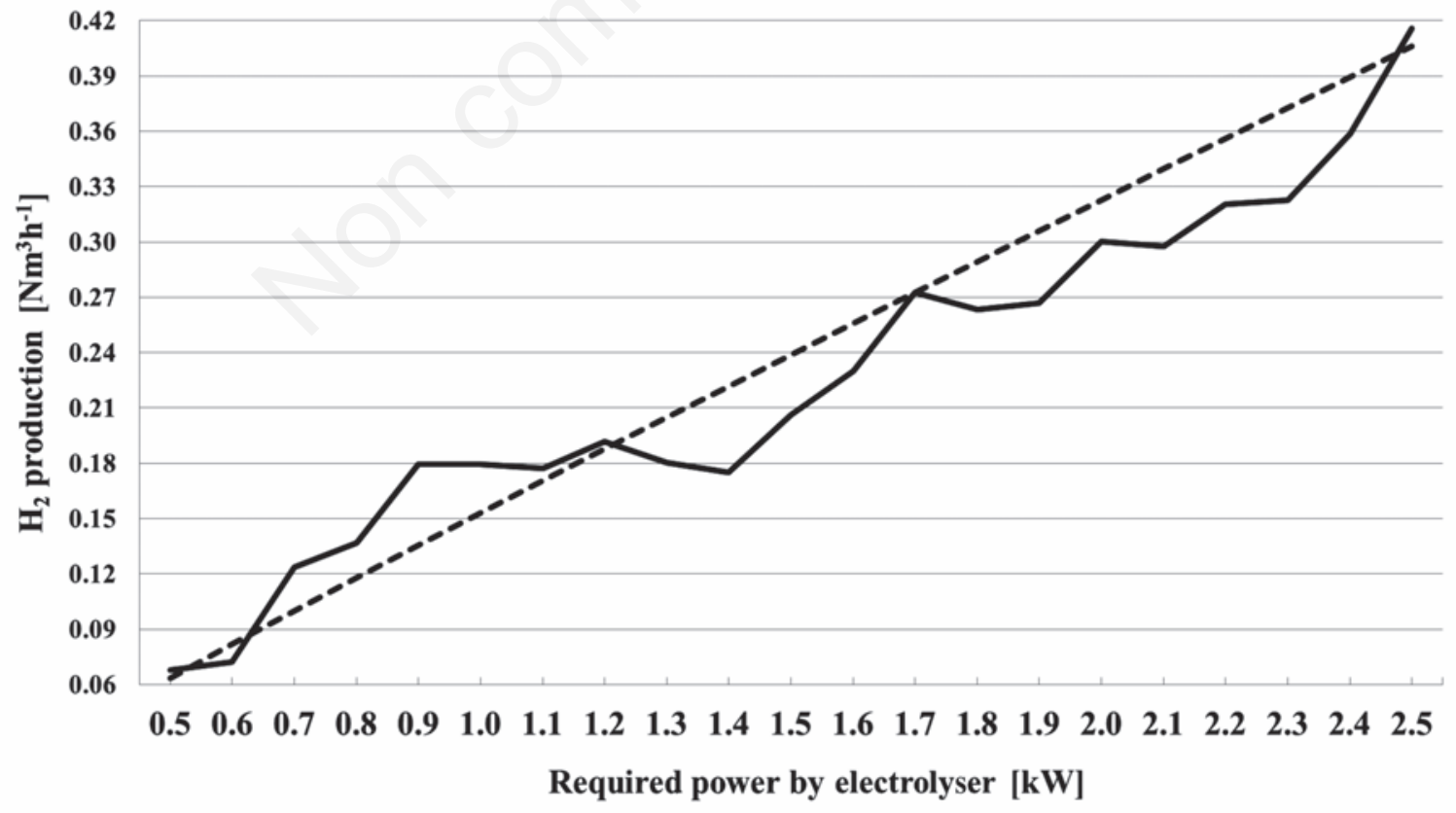

-Experimental - - Calculated

Figure 7. Comparison between experimental and calculated performance of the electrolyser: hydrogen production as a function of the required power. 


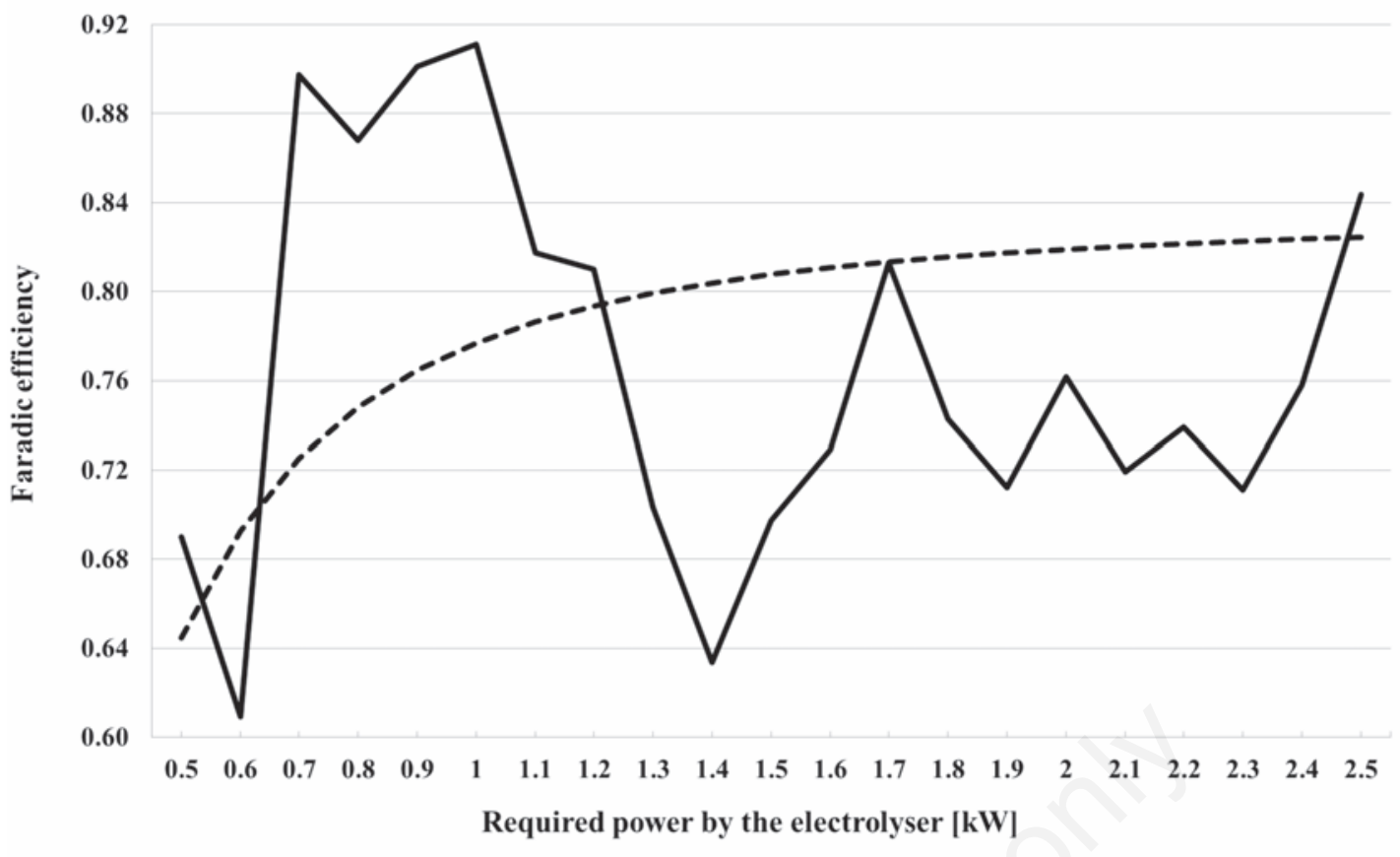

-- Calculated -Experimental

Figure 8. Comparison between experimental and calculated Faradic efficiency $\eta_{F}$ as a function of the required power of the electrolyser.

of the stack required power and consequently with the increasing of the $\mathrm{H}_{2}$ production. Furthermore $\eta_{F}$ increases of $25 \%(0.645 \div 0.808)$ in the range $0.5 \div 1.5 \mathrm{~kW}$ of the required power and only of $2 \%(0.808 \div 0.824)$ for required power in the range $1.5 \div 2.5 \mathrm{~kW}$. These results may highlight that the parasitic current losses inside electrolyser would become dramatic for $\mathrm{H}_{2}$ productions less than $0.21 \mathrm{Nm}^{3} \mathrm{~h}^{-1}$ corresponding to $1.5 \mathrm{~kW}$. Furthermore the suitable working range of the electrolyser is $1.5 \div 2.5 \mathrm{~kW}$ and then when the $\mathrm{H}_{2}$ production is greater than the aforesaid threshold value of $0.21 \mathrm{Nm}^{3} \mathrm{~h}^{-1}$.

\section{Conclusions}

Greenhouses are widespread in many nations and it is supposed for them further expansion particularly in the areas where climatic conditions are unfavourable. The commercial greenhouses require great energy consumption for their climate control in order to obtain good yield and high quality of horticultural products. Even if oil, natural gas and electric energy are generally used as fuels of heating systems, only the employment of renewable energies can increase the sustainability of the covered cultivation. Unfortunately renewable energy sources need a power back up arrangement due to their instability and uncertain availability. The storage of solar energy in the form of hydrogen $\left(\mathrm{H}_{2}\right)$ can be the basis for a totally renewable system aiming at greenhouse heating in a self-sustained way, composed by photovoltaic in combination with hydrogen produced by electrolysis, $\mathrm{H}_{2}$-storage and fuel cells connected to a ground source heat pump.

A greenhouse-integrated system composed of photovoltaic panels, alkaline barometric water electrolyser, fuel cell stacks and geothermal heat pump were set up at the experimental farm of the University of
Bari. The electricity coming from the solar photovoltaic source feeds the electrolyser and the hydrogen gas produced by water electrolysis is then stored in a pressure tank. When photovoltaic is not operating (during night time or overcast sky), it is used by a fuel cell system producing electricity to supply the geothermal heat pump for greenhouse heating. The electrolyser is a crucial component of this integrated system and the technical dare is to make it works regularly despite the irregular power from solar energy sources. Its performance was evaluated employing only the electrical power supplied by the PV modules during the period 1 to 31 March 2014, during which the solar radiation has been very unstable affecting the available electrical power produced by the PV. During the days characterised by partially cloudy sky, the action of the electrolyser was intermittent with several breakdowns of hydrogen production. On the contrary, during the days characterised by clear sky, the electrolyser worked continuously even if the $\mathrm{H}_{2}$ production was affected by the daytime variability of the solar radiation. Anyway the electrolyser worked continuously in a transient state producing fluctuations of the $\mathrm{H}_{2}$ production and without ever reaching the steady-state conditions. Furthermore the $\mathrm{H}_{2}$ rate flow increased with the increasing of the stack required power, even if by a not directly proportionality. The Faradic efficiency $\eta_{F}$ as a function of the required power by the electrolyser, experimentally evaluated, highlights the considerable unstableness of the working conditions of the electrolyser. Conversely the Faradic efficiency analysed by means of an empirical mathematic model, highlights that the suitable working range of the electrolyser was $1.5 \div 2.5 \mathrm{~kW}$ and then for $\mathrm{H}_{2}$ production more than 0.21 $\mathrm{Nm}^{3} \mathrm{~h}^{-1}$.

Finally this integrated power system based on photovoltaic energy and on the use of hydrogen as energy vector can supply the geothermal heat pump for greenhouse heating in a self-sustained way, even if its operational reliability must be fully evaluated. 


\section{References}

Adaro J.A., Galimberti P.D., Lema A.I., Fasulo A., Barral J.R. 1999. Geothermal contribution to greenhouse heating. Appl. Energ. 64: 241-9.

Baldoin C., Balsari P., Cerruto E., Pascuzzi S., Raffaelli M. 2008. Improvement in pesticide application on greenhouse crops: results of a survey about greenhouse structures in Italy. Acta Hort. 801:609-14.

Benli H. 2013. A performance comparison between a horizontal source and a vertical source heat pump systems for a greenhouse heating in the mild climate Elazig, Turkey. Appl. Therm. Eng. 50:197-206.

Casadei D., Grandi G., Rossi C., Paolone M. 2005. Impianto sperimentale per la produzione di energia elettrica fotovoltaica con sistema di accumulo ad idrogeno. Conf. Proc. Natl. Meeting on the Italian Energy Policy, 18-19 April 2004, University of Bologna, Italy. Available from: http://infoscience.epfl.ch/record/180175/files/ Impianto\%20sperimentale $\% 20$ per\%20la\%20produzione $\% 20 \mathrm{di} \% 20 \mathrm{e}$ nergia\%20elettrica\%20fotovoltaica\%20con\%20sistema\%20di\%20a ccumulo\%20ad\%20idrogeno.pdf Accessed: May 2013.

Chai L., Ma C., Ni J.Q. 2012. Performance evaluation of ground source heat pump system for greenhouse heating in norther China. Biosyst. Eng. 3:107-17.

Chiabrando R., Fabrizio E. 2009. La sostenibilità energetica delle costruzioni: criteri progettuali e strumenti di verifica. pp 4-7 in Proc. IX Naz. Congr. AIIA, Ischia, Italy.

David E., 2005. An overview of advanced materials for hydrogen storage. J. Mater. Process. Technol. 162-3, 169-77.

De Luca V., Manera C., Mazza S. 1996. Previsione del fabbisogno energetico per l'attività produttiva in serra sul territorio della Basilicata. Riv. Ing. Agr. 3:162-71.

De Pascale S., Maggio A. 2005. Sustainable protected cultivation at a mediterranean climate. Perspectives and challenges. Acta Hort. 691:29-42

Ganguly A., Misra D., Ghosh S. 2010. Modeling and analysis of solar photovoltaic-electrolyzer-fuel cell hybrid power system integrated with a floriculture greenhouse. Energ. Buildings. 42:2036-43.

Giacomelli G.A., Sase S., Cramer R., Hoogeboom J., MacKenzie A., Parbst K., Scarascia-Mugnozza G., Selina P., Sharp D.A., Voogt J.0., Van Weel P.A., Mears D. 2012. Greenhouse production systems for people. Acta Hort. 927:23-38.

Gómez X., Fernández C., Fierro J., Sánchez M.E., Escapa A., Morán, A. 2011. Hydrogen production: Two stage processes for waste degradation. Bioresour. Technol. 102:8621-7.

Hug W., Divisek J., Mergel J., Seeger W., Steeb H. 1992. Highly Efficient advanced alkaline electrolyzer for solar operation. Int. J. Hydrogen Energ. 17:699-705.

ISO (International Organisation for Standardisation). 1994. ISO 57251:1994. Accuracy (trueness and precision) of measurement methods and results - Part 1: General principles and definitions. International Organisation for Standardisation Publications, Geneva, Switzerland.

Jallouli R., Krichen L. 2012. Sizing, techno-economic and generation management analysis of a stand alone photovoltaic power unit including storage devices. Energy. 40:196-209.

Kapdan I.K., Kargi F. 2006 Bio-hydrogen production from waste materials. Enzym. Microb. Technol. 38:569-82.

Khan M.J., Iqbal M.T. 2005. Pre-feasibility study of stand-alone hybrid energy systems for applications in Newfoundland. Renew. Energ. 30:835-54

Kondili E., Kaldellis J.K. 2006. Optimal design of geothermal-solar greenhouses for the minimisation of fossil fuel consumption. Appl. Therm. Eng. 26:905-15.

Li C.H., Zhu X.J., Cao G.Y., Sui S., Hu M.R. 2009. Dynamic modeling and sizing optimization of stand-alone photovoltaic power systems using hybrid energy storage technology. Renew. Energ. 34:815-26.

Maclay J.D., Brouwer J., Samuelsen G.S. 2011. Experimental results for hybrid energy storage systems coupled to photovoltaic generation in residential applications. Int. J. Hydrogen Energ. 36:12130-40.

Mueller-Langer F., Tzimas E., Kaltschmitt M., Peteves S. 2007. Technoeconomic assessment of hydrogen production processes for the hydrogen economy for the short and medium term. Int. J. Hydrogen Energ. 32:3797-810.

Ntaikou I., Antonopoulou G., Lyberatos G. 2010. Biohydrogen production from biomass and wastes via dark fermentation: a review. Waste Biomass Valor. 1:21-39.

Ozgener 0.2010. Use of solar assisted geothermal heat pump and small wind turbine systems for heating agricultural and residential buildings. Energy 35:262-8.

Redwood M.D., Paterson-Beedle, M., Macaskie L.E. 2009. Integrating dark and light bio-hydrogen production strategies: towards the hydrogen economy. Rev. Environ. Sci. Biotechnol. 8:149-85.

Scarascia-Mugnozza G., Anifantis A. 2009. Dal fotovoltaico al termico. Colture Protette 6:40-3.

Scarascia-Mugnozza G., Pascuzzi S., Anifantis A., Verdiani G. 2011. Photovoltaic and geothermal integration system for greenhouse heating: an experimental study. pp 135-138 in Proc. 5th Int. Sci. Symp. Farm Machinery and Process Management in Sustainable Agricolture, Lublin, Poland.

Schettini E., de Salvador F.R., Scarascia-Mugnozza G., Vox G. 2011. Radiometric properties of photoselective and photoluminescent greenhouse plastic films and their effects on peach and cherry tree growth. J Hortic. Sci. Biotech. 86:79-83.

Sioli G. 2014. High pressure electrolyzer. United States Patent. Available from: http:/worldwide.espacenet.com/publicationDetails/ biblio;jsessionid=3B8961542034B3972FAFF4E13987BBC4.espacen et_levelx_prod_2? $\mathrm{FT}=\mathrm{D} \&$ date $=20100506 \& \mathrm{DB}=\& \& \mathrm{CC}=\mathrm{CA} \& \mathrm{NR}=2$ 739019A1\&KC $=\mathrm{A} 1 \& \mathrm{ND}=1$ \&locale $=$ en_EP Accessed: May 2014 .

Ulleberg $\emptyset .2003$. Modeling of advanced alkaline electrolyzers: A system simulation approach. Int. J. Hydrogen Energ. 28:21-33.

Valdés R., Rodríguez L.R., Lucio J.H. 2012. Procedure for optimal design of hydrogen production plants with reserve storage and a standalone photovoltaic power system. Int. J. Hydrogen Energ. 37:4018-25.

von Zabeltitz, C. 1999. Greenhouse structures. In: G. Stanhill and H. Zvi Enoch (eds), Greenhouse ecosystems. Elsevier, Amsterdam, the Netherlands, pp 17-69.

Vox G., Schettini E., Lisi Cerone A., Anifantis A. 2008. Solar thermal collectors for greenhouse heating. Acta Hort. 801:787-94.

Vox G., Teitel M., Pardossi A., Minuto A., Tinivella F., Schettini E. 2010. Sustainable greenhouse systems, sustainable agriculture: technology, planning and management. Nova Science Publishers, New York, NY, USA.

Walker J.N., Short T.H. 1983. Quantity of air flow for agricultural structures. In: Mylo A. Hellickson and John N. Walker (eds), Ventilation of agricultural structures. American Society of Agricultural Engineers, St. Joseph, MI, USA, pp 257-77.

Züttel A. 2003. Materials for hydrogen storage. Mater. Today 6:24-33. 